\title{
Linguistic Models
}

The publications in this series tackle crucial problems, both empirical and conceptual, within the context of progressive research programs. In particular Linguistic Models will address the development of formal methods in the study of language with special reference to the interaction of grammatical components.

Series Editors:

Teun Hoekstra

Harry van der Hulst

Other books in this series:

1 Michael Moortgat, Harry van der Hulst and Teun Hoekstra (eds) The Scope of Lexical Rules

2 Harry van der Hulst and Norval Smith (eds) The Structure of Phonological Representations. Part I

3 Harry van der Hulst and Norval Smith (eds) The Structure of Phonological Representations. Part II

4 Gerald Gazdar, Ewan Klein and Geoffrey K. Pullum (eds) Order, Concord and Constituency

5 W. de Geest and Y. Putseys (eds) Sentential Complementation

6 Teun Hoekstra Transitivity. Grammatical Relations in Government-Binding Theory

7 Harry van der Hulst and Norval Smith (eds) Advances in Nonlinear Phonology

8 Harry van der Hulst Syllable Structure and Stress in Dutch

9 Hans Bennis Gaps and Dummies

10 Ian G. Roberts The Representation of Implicit and Dethematized Subjects

11 Harry van der Hulst and Norval Smith (eds) Autosegmental Studies on Pitch Accent

12 Harry van der Hulst and Norval Smith (eds) Features, Segmental Structure and Harmony Processes (Part II)

13 D. Jaspers, W. Klooster, Y. Putseys and P. Seuren (eds) Sentential Complementation and the Lexicon

14 René Kager A Metrical Theory of Stress and Destressing in English and Ducth

15 I.M. Roca (ed.)

Logical Issues in Language Acquisition 


\section{Thematic Structure Its Role in Grammar}

I.M. Roca (ed.)

FORIS PUBLICATIONS

Berlin • New York 1992 
Foris Publications Berlin • New York (formerly Foris Publications, Dordrecht) is a Division of Walter de Gruyter \& Co., Berlin.

(9) Printed on acid-free paper which falls within in the guidelines of de ANSI to ensure permanence and durability.

\section{Library of Congress Cataloging in Publication Data}

Thematic structure : its role in grammar/I.M. Roca, ed.

p. cm. - (Linguistic models; 16)

Includes bibliographical references and indexes.

ISBN 3-11-013406-3 (alk. paper)

1. Grammar, Comparative and general - Topic and comment. I. Roca, Iggy. II. Series.

P298.T47 1992

91-46344

415-dc20

CIP

Die Deutsche Bibliothek Cataloging in Publication Data

Thematic structure : its role in grammar / I.M. Roca, (ed.) -

Berlin ; New York : Foris Publ., 1992

(Linguistic models ; 16)

ISBN 3-11-013406-3

NE: Roca, Iggy M. [Hrsg.]; GT

- Copyright 1992 by Walter de Gruyter \& Co., D-1000 Berlin 30

All rights reserved, including those of translation into foreign languages. No part of this book may be reproduced or transmitted in any form or by any means, electronic or mechanical, including photocopy, recording, or any information storage and retrieval system, without permission in writing from the publisher.

Printing: ICG Printing, Dordrecht

Printed in The Netherlands. 


\section{Table of Contents}

List of Contributors $\quad$ xi

Foreword $\quad$ xv

Martin Atkinson

Introduction $\ldots \ldots \ldots \ldots \ldots \ldots \ldots \ldots \ldots \ldots \ldots \ldots \ldots \ldots \ldots \ldots$

\section{Mark C. Baker}

Thematic conditions on syntactic structures:

evidence from locative applicatives $\ldots \ldots \ldots \ldots \ldots \ldots \ldots \ldots \ldots \ldots \ldots$

1. Background: benefactive and instrumental applicatives ....... 25

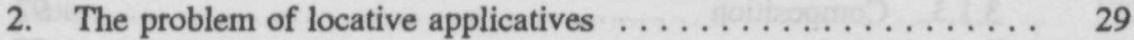

2.1. Chichewa ......................... 29

2.2. Kinyarwanda and Sesotho $\ldots \ldots \ldots \ldots \ldots \ldots \ldots \ldots \ldots$

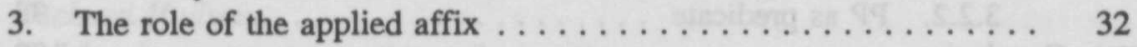

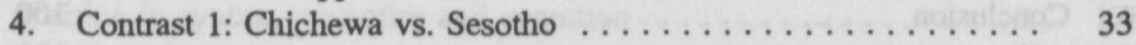

5. Contrast 2: Kinyarwanda vs. Chichewa/Sesotho ......... 38

6. Chichewa benefactive applicatives revisited .......... 40

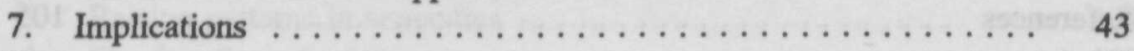

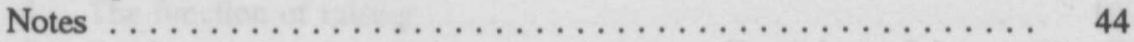

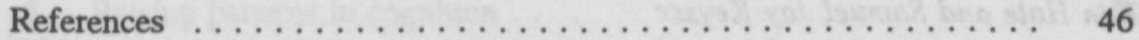

Geert Booij

Morphology, semantics and argument structure $\ldots \ldots \ldots \ldots \ldots \ldots 47$

1. Introduction $\ldots \ldots \ldots \ldots \ldots \ldots \ldots \ldots \ldots \ldots \ldots \ldots \ldots$

2. Lexical-conceptual structure $\ldots \ldots \ldots \ldots \ldots \ldots \ldots \ldots \ldots . \ldots . \ldots . \ldots$

3. Morphological operations on LCS .............. 51

4. Verbal prefixation and LCS ................ 54

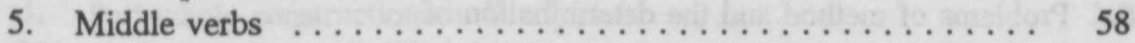

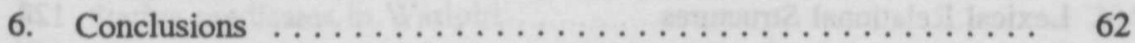

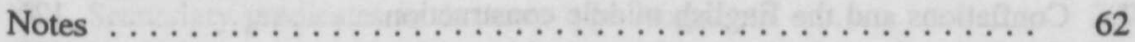

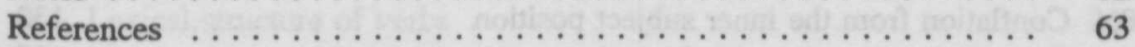


Anna-Maria Di Sciullo

Deverbal compounds and the external argument ........... 65

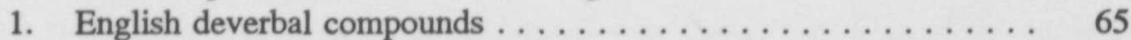

2. Italian deverbal compounds $\ldots \ldots \ldots \ldots \ldots \ldots \ldots \ldots \ldots \ldots \ldots$

3. Italian and English . . . . . . . . . . . 71

4. English deverbal compounds revisited $\ldots \ldots \ldots \ldots \ldots \ldots \ldots 73$

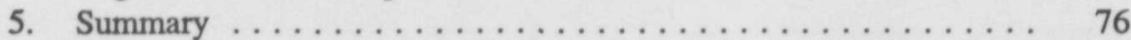

Notes ............................. 76

References ....................... 78

Carlos Gussenhoven

Sentence accents and argument structure . . . . . . . . . 79

1. Bresnan's account: the Nuclear Stress Rule . . . . . . . . 80

2. The generalization $\ldots \ldots \ldots \ldots \ldots \ldots \ldots \ldots \ldots \ldots \ldots \ldots$

2.1 Difficulty of perceiving nonfinal accents $\ldots \ldots \ldots \ldots \ldots 87$

2.2. Two PP's in one argument . . . . . . . . . . . 88

3. Exploiting the generalization $\ldots \ldots \ldots \ldots \ldots \ldots \ldots \ldots \ldots . \ldots \ldots$

3.1 Multiword predicates $\ldots \ldots \ldots \ldots \ldots \ldots \ldots \ldots \ldots . \ldots \ldots$

3.1.1. Natural predicates . . . . . . . . . . . 89

3.1.2. Newman's pair $\ldots \ldots \ldots \ldots \ldots \ldots \ldots \ldots \ldots . \ldots . \ldots$

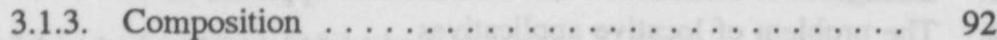

3.2. Embedded clauses $\ldots \ldots \ldots \ldots \ldots \ldots \ldots \ldots \ldots \ldots \ldots$

3.2.1. "Raising" vs. "Equi-NP" constructions ........ 95

3.2.2. $\mathrm{PP}$ as predicate $\ldots \ldots \ldots \ldots \ldots \ldots \ldots \ldots \ldots$

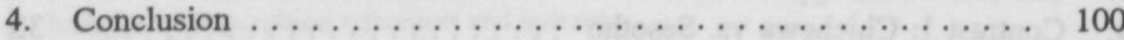

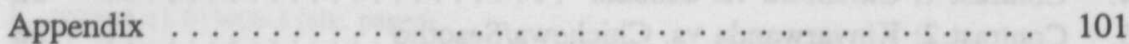

Notes ............................. 104

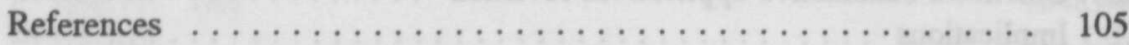

Ken Hale and Samuel Jay Keyser

The syntactic character of thematic structure . . . . . . . . . . 107

0 . Introduction $\ldots \ldots \ldots \ldots \ldots \ldots \ldots \ldots \ldots \ldots \ldots \ldots \ldots \ldots \ldots \ldots \ldots \ldots \ldots$

1. The double object construction $\ldots \ldots \ldots \ldots \ldots \ldots \ldots \ldots \ldots . \ldots 108$

2. Conflation as incorporation $\ldots \ldots \ldots \ldots \ldots \ldots \ldots \ldots \ldots \ldots 111$

3. Other patterns of conflation $\ldots \ldots \ldots \ldots \ldots \ldots \ldots \ldots \ldots \ldots$

4. Lexical representations $\ldots \ldots \ldots \ldots \ldots \ldots \ldots \ldots \ldots \ldots \ldots \ldots$

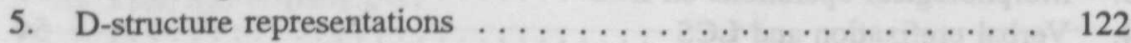

6. Problems of method and the determination of

7. Conflations and the English middle construction . . . . . . 126

8. Conflation from the inner subject position $\ldots \ldots \ldots \ldots \ldots \ldots .132$

9. The relational structures of location and locatum verbs ....... 135 
10. Functional categories in the lexicon . . . . . . . . . . 136

11. Some final remarks $\ldots \ldots \ldots \ldots \ldots \ldots \ldots \ldots \ldots \ldots$

Notes . . . . . . . . . . . . . . . . . . . . . . 140

References .......................... 141

\section{Teun Hoekstra}

Aspect and Theta Theory $\ldots \ldots \ldots \ldots \ldots \ldots \ldots \ldots \ldots \ldots \ldots$

1. The problem ...................... 145

2. Resultatives .......................... 146

2.1. Small clauses . . . . . . . . . . . . . . . 146

2.2. Resultatives .................... 150

2.3. Conclusion $\ldots \ldots \ldots \ldots \ldots \ldots \ldots \ldots \ldots \ldots \ldots \ldots \ldots$

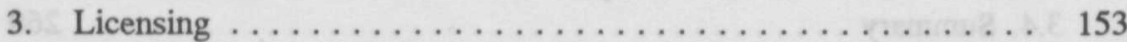

3.1. The theory of modification . . . . . . . . . . . . . 154

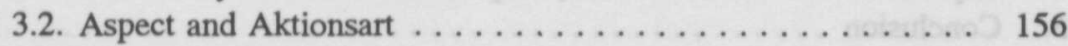

3.3. Licensing Resultatives $\ldots \ldots \ldots \ldots \ldots \ldots \ldots \ldots \ldots \ldots 16 \ldots \ldots$

3.4. Accomplishments . . . . . . . . . . . . . . 162

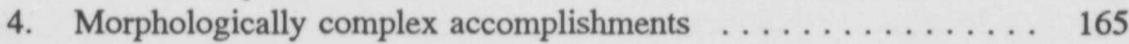

5. Morphologically simplex verbs . . . . . . . . . . . . . 169

6. Conclusion $\ldots \ldots \ldots \ldots \ldots \ldots \ldots \ldots \ldots \ldots \ldots \ldots \ldots \ldots \ldots \ldots$

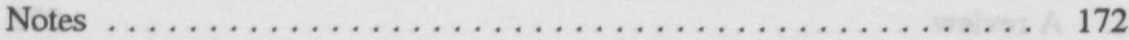

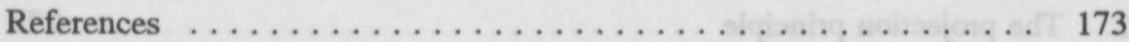

\section{Richard Hudson}

Raising in syntax, semantics and cognition . . . . . . . . . . 175

1. Introduction and overview $\ldots \ldots \ldots \ldots \ldots \ldots \ldots \ldots \ldots \ldots \ldots$

2. Raising patterns in $\operatorname{syntax} \ldots \ldots \ldots \ldots \ldots \ldots \ldots \ldots \ldots \ldots$

3. Raising patterns in semantics $\ldots \ldots \ldots \ldots \ldots \ldots \ldots \ldots \ldots \ldots \ldots$

4. The function of raising $\ldots \ldots \ldots \ldots \ldots \ldots \ldots \ldots \ldots \ldots \ldots \ldots$

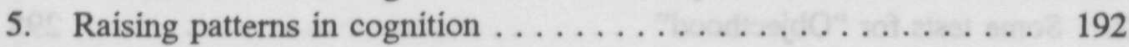

6. Conclusion ......................... 196

Notes . . . . . . . . . . . . . . . . . . . . . . . . . . . 197

References ........................... 197

\section{Mary Laughren}

Secondary predication as a diagnostic of underlying structure in

Pama-Nyungan languages . . . . . . . . . . . . . . . . . . . . . 199

1. Part-whole constructions in Warlpiri ............... 200

2. Stative predicates in Warlpiri ................ 204

3. Secondary predicates in Arrernte-type languages . . . . . . . . . 207

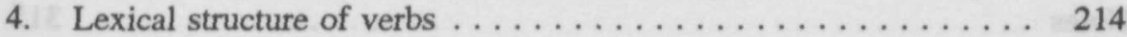

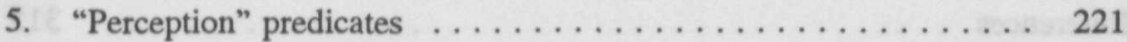

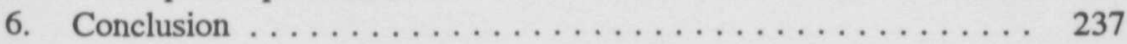


Notes ............................. 240

References ........................ 245

Beth Levin and Malka Rappaport Hovav

The lexical semantics of verbs of motion:

the perspective from unaccusativity $\ldots \ldots \ldots \ldots \ldots \ldots \ldots \ldots 247$

1. Verbs of motion: a problem for the unaccusative hypothesis? . . . 251

2. Three classes of verbs of motion $\ldots \ldots \ldots \ldots \ldots \ldots \ldots \ldots \ldots 252$

3. Correlations of meaning components with unaccusativity $\ldots \ldots \ldots 253$

3.1. Arrive verbs . . . . . . . . . . . . . . . 253

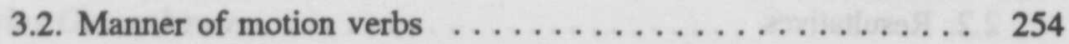

3.3. Run verbs with directional phrases $\ldots \ldots \ldots \ldots \ldots \ldots 258$

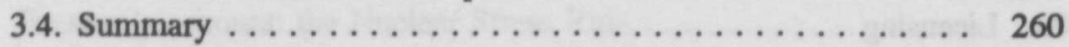

4. Implications for lexical semantic representation $\ldots \ldots \ldots \ldots \ldots 260$

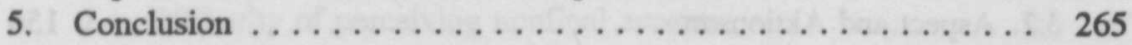

Notes ............................ 265

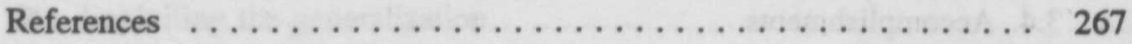

\section{Rita Manzini}

The projection principle(s): a reexamination $\ldots \ldots \ldots \ldots \ldots \ldots \ldots 271$

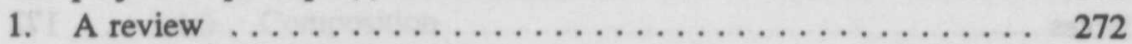

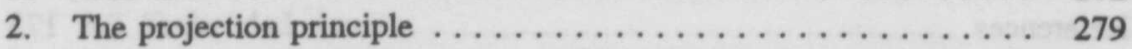

3. The projection principle and the extended projection principle . . 285

References ............................. 291

\section{John Charles Smith}

Circumstantial complements and direct objects in the Romance languages: configuration, Case, and thematic structure ... . . . . . 293

1. A traditional view of the problem . . . . . . . . . . . 293

2. Some tests for "Objecthood" ... . . . . . . . . . . . . . 295

2.1. Commutation tests . . . . . . . . . . . . . 295

2.2. Passive constructions .................... 297

2.3. Causative constructions . . . . . . . . . . . . . 298

2.4. Auxiliary selection $\ldots \ldots \ldots \ldots \ldots \ldots \ldots \ldots \ldots \ldots \ldots$

2.5. Extraction $\ldots \ldots \ldots \ldots \ldots \ldots \ldots \ldots \ldots \ldots \ldots \ldots \ldots \ldots \ldots$

2.6. Cliticization $\ldots \ldots \ldots \ldots \ldots \ldots \ldots \ldots \ldots \ldots \ldots \ldots \ldots \ldots \ldots$

3. A configurational account . . . . . . . . . . . . . . 303

4. Case and Theta-Role assignment ................. 306

5. Some further data $\ldots \ldots \ldots \ldots \ldots \ldots \ldots \ldots \ldots \ldots \ldots \ldots$

6. Conclusion $\ldots \ldots \ldots \ldots \ldots \ldots \ldots \ldots \ldots \ldots \ldots \ldots \ldots \ldots \ldots \ldots$

Notes . . . . . . . . . . . . . . . . . . . . 315

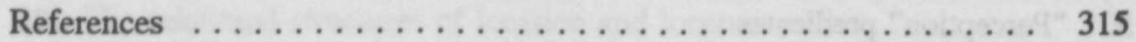




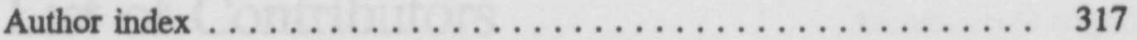

Subject index 


\title{
Morphology, semantics and argument structure
}

\author{
Geert Booij \\ Free University of Amsterdam
}

\section{INTRODUCTION}

Traditionally, morphology deals primarily with the internal structure of complex words, the internal syntax of words. However, morphological theory also has to account for the effects of morphological processes on the syntactic valency of the words they create, the so-called external syntax of words.

The minimal level of abstraction that is required to account for the syntactic effects of morphology is the level of argument structure. For instance, the wellknown correspondence between verbs and deverbal nominalizations can only be expressed at the level of argument structure (Amritavalli 1980, Rappaport 1983). Consider, for instance, the data in (1):
a. John refuses the offer
b. *John refusal the offer
c. John's refusal of the offer/the refusal of the offer by John

In (1), the verb refuse and the deverbal noun refusal have the same argument structure, with two arguments, usually called Agent and Theme. The differences in the syntactic realization of these arguments are determined by independent syntactic principles: (1b) is ungrammatical because the nominal head refusal does not assign case to postnominal complements (and hence they have to be governed by prepositions), and requires prenominal complements to bear the genitive case ('s). These requirements are fulfilled in (1c). Note that in this case of deverbal nominalization the argument structure of the input words is not different from that of the output words. This phenomenon is referred to as 'inheritance' of argument structure.

There are also morphological processes in which the argument structure, and hence the syntactic valency of input words and output words differ. In a by now classic paper, Williams (1981) argued that the effects of morphological processes on syntactic valency should be described in terms of operations on argument structure (i.e. $\theta$-grids). The $\theta$-grid of each verb consists of one or more $\theta$-roles. At most one of these is external (indicated by underlining), i.e. has to be realized as subject, outside the VP of which the verb is the head. The other arguments are internal. Following Marantz (1984) and Levin and 
Rappaport (1986) we distinguish two kinds of internal arguments, direct and indirect ones. A direct argument is realized as a bare NP whereas an indirect argument is realized as an NP with some oblique case (eg. dative) or as a PP.

Williams claimed that morphological operations on argument structure are restricted to the following ones:

(a) $\quad \mathrm{E}(\mathrm{X})$ : 'Externalize the internal argument, and make the original external argument internal' (for example -able-suffixation, in which according to Williams the Theme of the verb is externalized, and the Agent internalized: read $\mathrm{Ag}, \mathrm{Th} \rightarrow$ readable $\underline{\mathrm{Th}}, \mathrm{Ag}$ ). That is, $\mathrm{X}$ has the value 'Th' here);

(b) $\mathrm{E}(0)$ : 'Make the external argument internal' (e.g. see $\mathrm{Ag} \mathrm{Th} \rightarrow$ seen $\mathrm{Ag}$ Th);

(c) $\mathrm{I}(\mathrm{X})$ : 'Internalize the external argument, and add a new external argument' (e.g. random $\mathrm{Th} \rightarrow$ randomize $\mathrm{Ag} \mathrm{Th}$ ).

Williams' proposal entails that morphological rules can refer to the content of $\theta$-roles. For instance, the characterization of -ize-suffixation refers to the $\theta$-role 'Theme'. In the more recent literature on this issue we also find the more restrictive claim that morphological rules do operate on argument structure, but do not refer to the content of $\theta$-roles. I.e., morphological rules can only refer to notions such as 'external argument' and 'internal argument' (Levin and Rappaport 1986, Fagan 1988).

The hypotheses that I will defend in this paper are the following:

(i) The lexical representation of verbs contains, apart from phonological information, at least the following two, related, levels: Lexical-Conceptual Structure (LCS) and Predicate-Argument Structure (PAS), where PAS is a projection of LCS;

(ii) Morphological rules may either apply at the level of LCS (and hence may also indirectly affect PAS), or the level of PAS.

If these hypotheses are correct, they refute Jackendoff's (1987: 379) claim that there is no motivation for a level of PAS in addition to the level of LCS.

The paper also lends support to the claim that $\theta$-roles do not play a role in morphology, contrary to Williams' (1981) position.

\section{LEXICAL-CONCEPTUAL STRUCTURE}

In the spirit of Hale and Keyser (1986), Zubizarreta (1987) and Rappaport, Levin and Laughren (1988), we distinguish between two levels in the lexical representations of verbs: LCS and PAS. For instance, the lexical representation of the transitive verb to eat can be represented as follows: 
(2)

\author{
eat \\ LCS: $[x \text { EAT y }]_{\text {ACTION }}$ \\ PAS: V; $\underline{x}, \underline{y}$
}

LCS specifies the semantic structure of the verb to eat: it expresses a specific action, which is indicated by the concept EAT, an action in which two participants are involved, indicated by the ordered pair of variables $x$ and $y$ (traditionally referred to as the logical subject and the logical object respectively). The concept EAT may be decomposable into smaller conceptual units, among which the concept ACTION. The minimal assumption that we make here is that EAT is categorized as a instantiation of the category of ACTIONs.

The level of PAS not only specifies the number of arguments that have to be realized syntactically, but also contains a minimal form of syntactic annotation: it specifies that the first argument is the external argument, to be realized as subject, and that the other argument is the direct internal argument. Thus, the level of PAS can be qualified as containing "those aspects of lexical meaning that are grammatically relevant" (Zubizarreta 1987) or as "the part of conceptual structure that is visible to the syntax" (Jackendoff 1987: 405). It is PAS that mediates the mapping of LCS onto syntactic structure. At the level of LCS we specify that to eat is an action with two participants. Since eat expresses an action, the logical subject, i.e. the eater, predictably belongs to the class of agents, and the logical object, that which is eaten, belongs to the class of patients.

Labels such as ACTION are motivated in Jackendoff (1983). ${ }^{1}$ They are necessary for a proper account of the aspectual properties of sentences. We also need them for making generalizations concerning the relation between LCS and PAS. For instance, it is a well established universal rule (cf. Anderson 1977) that "in all languages, agent theta roles are external, and patient/theme theta roles are internal when a verb has both" (Baker 1988: 37). Note that we can make this generalization without assigning labels for specific $\theta$-roles at the level of PAS: the relevant generalization can be made by referring to the level of LCS, where the conceptual unit ACTION is available. As Jackendoff (1987: 378) puts it: "thematic relations are to be reduced to structural configurations in conceptual structure; the names for them are just convenient mnemonics for particularly prominent configurations".

Furthermore, the syntactic realization of the two arguments as bare NPs is the normal realization of external and direct internal arguments, and hence also predictable.

It is a matter of discussion whether we also need a level of syntactic subcategorization in addition to LCS and PAS, given the fact that PAS already contains a minimal form of syntactic information. I will assume here that such a third level is superfluous, probably with the exception of lexical idioms such as to look for, to look after, etc., where the selection of the proper preposition cannot be predicted on semantic grounds. 
As already pointed out above, I will support the claim (made by e.g. Zubizarreta (1987), Rappaport et al (1988) and Di Sciullo (1988)) that $\theta$-role labels do not play a role in morphology. Their claim is that the only information concerning arguments at PAS is whether they are external or internal, and whether they are direct or indirect. Note that this position does not affect the possibility of making the generalization that in a PAS with an Agent and a Theme, the Agent is the external argument: as pointed out above, this can also be expressed directly, without the $\theta$-role labels as intermediaries: the logical subject of an ACTION always projects as an external argument.

A first, non-morphological illustration of the different roles of LCS and PAS can be given by comparing the transitive verb to eat with its intransitive counterpart. At the level of LCS, both have a logical object. However, in the intransitive use of to eat, the value of the object variable has been fixed as 'food', whereas in the case of the transitive verb the object still is a variable at the level of PAS. Hence, although there is nothing wrong with the sentence John eats paper, the sentence John eats can only be interpreted as stating that John eats food. Therefore, the lexical representation of intransitive to eat is as follows:

$$
\begin{aligned}
& \text { LCS: } x \text { EAT } y, y=\text { FOOD } \\
& \text { PAS: } V ; \underline{x}
\end{aligned}
$$

Since the logical object is a constant at the level of LCS (the $y$-variable is bound by the conceptual unit FOOD), it is no longer a variable, and hence it cannot be projected on the level of PAS, and hence this verb is intransitive.

Another illustration of the differences between LCS and PAS is provided by the lexical representations of the transitive and the ergative to break:

$$
\begin{array}{ll}
\text { transitive } & \text { ergative } \\
\text { LCS: }\left[\mathrm{x} \text { CAUSE }[(\mathrm{y} \text { BREAK })]_{\text {PROCESS }}\right]_{\mathrm{ACTION}} & {[\mathrm{y} \text { BREAK }]_{\text {PROCESS }}} \\
\text { PAS: } \mathrm{V} ; \underline{\mathrm{x}}, \mathrm{y} & \mathrm{V} ; \mathrm{y}
\end{array}
$$

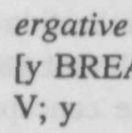

These representations express that the differences between the two verbs to break at the level of PAS (two arguments versus one argument) reflect a more specific semantic difference at the level of LCS: the Agent of the transitive verb expresses the causer of the process BREAK (where BREAK may be further decomposed into COME TO BE BROKEN). Moreover, PAS also expresses that the only argument of the ergative to break is an internal argument which is a sister of the $\mathrm{V}$ at the level of deep structure, the so-called ergative hypothesis (cf. Hoekstra 1984 for a survey of the arguments for this interpretation of verbs such as to break). The syntactic property of ergativity for the superficially intransitive verbs such as to break follows from the generalization that verbs that indicate a change of state are normally ergative. 


\section{MORPHOLOGICAL OPERATIONS ON LCS}

Given the assumption outlined above that the lexical representations of verbs contains at least the levels of LCS and PAS, the question now arises whether morphological rules apply to LCS or to PAS. Below, I will show that both kinds of morphological processes have to be allowed for, i.e. some rules apply at the level of LCS, whereas other rules apply at the level of PAS.

Knopper (1984) has shown that the Dutch deverbal suffix -sel has to be qualified as a suffix that creates names that refer to the internal argument of the verb. This is illustrated in (5): in (5a) we find object names derived from transitive verbs, (5b) shows examples of -sel-nouns derived from ergative verbs which have only one argument. The criteria for the ergativity of Dutch verbs are taken from Hoekstra (1984). One of them is that ergative verbs select the auxiliary verb zijn 'to be' instead of hebben 'to have' which is selected by intransitive and transitive verbs. The examples are from Knopper (1984):
a. tik-sel 'typing' bak-sel 'baking' uitwerp-sel 'excrement'
from tik 'to type-write' bak 'to bake'
b. aanslib-sel 'deposit' verschijn-sel 'phenomenon' bezink-sel 'sediment' uitwerp 'to excrete' aanslib 'to form a deposit' verschijn 'to appear' bezink 'to settle'

Crucially, intransitive, non-ergative verbs do no allow for -sel-suffixation, and hence the relevant generalization can only be stated at the level of PAS: at the level of LCS the arguments of intransitive verbs have the same status as those of ergative verbs, that of 'logical subject'. It is at the level of PAS that the syntactic difference between them (external versus internal argument) is stated, and therefore, the relevant word formation rule has to apply at PAS.

A second example of a word formation process that is to be accounted for at the level of PAS is the formation of deverbal -er-nouns in English. Levin and Rappaport (1988) have argued that the relevant generalization is that deverbal -er creates nouns that refer to the external argument of verbs. Thus, it is predicted that -er does not attach to ergative verbs, and that, for instance, the following nouns are ill-formed (Levin and Rappaport 1988: 1075):

$$
\begin{aligned}
& \text { *disappearer, *happener, *dier, *laster, *ender, *exister, *occurrer, } \\
& \text { *collapser }
\end{aligned}
$$

However, these analyses should not be taken to imply that all morphological processes apply at the level of PAS. Below, I will discuss a number of morphological processes that must be accounted for in terms of an operation on the LCS of verbs, with concomitant effects on PAS, and hence on syntactic valency. 
The first case study is that of deverbal nouns in -er in Dutch, which look similar to those of English. The suffix -er creates so-called subject names, as illustrated in (7). The base verbs are given in their citation form, the infinitive, which consists of stem + -en:
spel-er 'player'
$<$ spelen 'to play'
fiets-er 'cyclist'
$<$ fietsen 'to cycle'
prat-er 'talker'
$<$ praten 'to talk'

As pointed out in Booij (1986), deverbal -er-suffixation not only creates agent nouns, but also nouns with non-agentive interpretation, for instance:
lijd-er 'sufferer'
$<$ lijden 'to suffer'
(alles)kunn-er 'lit. all-canner, who can do everything'
hebb-er 'lit. haver, vulture'
$<$ kunnen 'can'
durv-er 'lit. darer, daredevil'
$<$ hebben 'to have'
$<$ durven 'to dare'

This already shows that this word formation process should not refer to theta role labels such as Agent, but only to the notion 'subject'. The question now is, whether this notion 'subject' refers to PAS and hence to the notion 'external argument', or to LCS, i.e. to the notion 'logical subject'. Hoekstra (1984) has argued that the notion 'external argument' is crucial, because -er cannot attach to ergative verbs. That is, Dutch $-e r$ is claimed to behave like its English counterpart. However, Booij (1986) argued that this claim is empirically incorrect, because there is a substantial number of -er-nouns derived from ergative verbs. Moreover, this class does not form a closed set, and can be extended. Examples of this class of nouns derived from ergative verbs are given in (9):

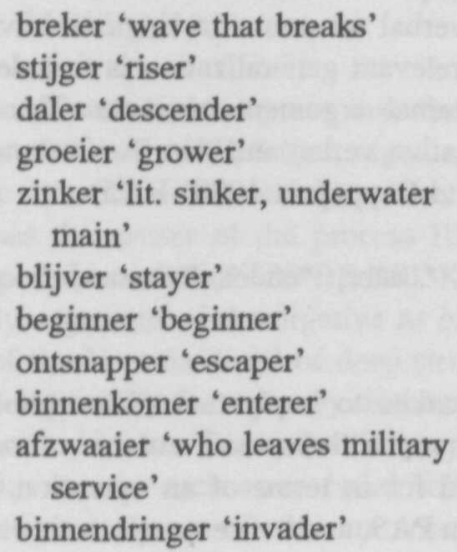

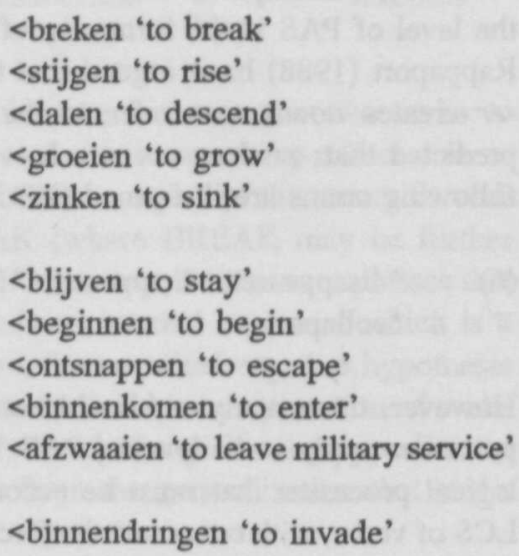




\author{
uitvaller 'drop out' \\ meevaller 'piece of good luck' \\ afvaller 'drop out' \\ invaller 'stand in' \\ insluiper 'sneak-thief'
}

\author{
<uitvallen 'to drop out' \\ $<$ meevallen 'turn out to be better \\ than expected' \\ $<$ afvallen 'to drop out' \\ $<$ invallen 'to stand in' \\ $<$ insluipen 'to sneak in'
}

Clearly then, the only valid generalization is that Dutch deverbal -er creates names for logical subjects, that is, subjects at the level of LCS. It is true that certain ergative verbs do not have a related noun in -er. For instance, the Dutch counterpart of English *appearer, blijker, does not exist, and this was one of the facts that Hoekstra (1984) adduced in favour of the hypothesis that -er does not attach to ergative verbs. Note, however, that the verb schijnen 'to seem' also does not allow for-er-suffixation, although it is not ergative. Some independent explanation should therefore be sought for the illformedness of *blijker and *schijner. Note, for instance, that -er creates names for entities, whereas the subject of the verbs blijken and schijnen is a proposition. This semantic 'clash' may therefore explain the illformedness of these words in -er.

Another morphological process that, I would like to argue, applies at LCS is Dutch deverbal -baar-suffixation, comparable to -able-suffixation in English. Recall that Williams (1981) qualified -able-suffixation as an operation by which the original internal argument becomes external, and vice versa. For instance, read $\mathrm{Ag}$ Th becomes readable Th Ag. However, in Dutch -baar-suffixation the Agent-argument is clearly lost: ${ }^{2}$
a. Dit verschijnsel is verklaarbaar (*door $\mathrm{mij})$
'This phenomenon is explainable (*by me)'
b. Dit boek is goed leesbaar (*door mij)
'This book is well readable (*by me)'

The loss of the the Agent argument also manifests itself in the fact that the Agent argument no longer functions as an implicit argument that can play a role in control, and in this respect -baar/-able suffixation differs from the passive:

a. *This book is readable to learn the facts of life

b. This book was read to learn the facts of life

The semantic characteristic of -baar-suffixation is that it creates adjectives which express a potentiality property of the Theme-argument with respect to the action expressed by the base verb. The agent phrase (by-PP) that occurs with passives, is not permitted here. Instead, it is possible to use the PP voor mij 'for me': Dit boek is goed leesbaar voor mij 'This book is well readable for me'. Note that voor mij is not an agentive phrase, but is rather used in combination 
with expressions that denote properties, as in Die jurk is leuk voor mij 'That dress is nice for me', with the underived adjective leuk 'nice'.

Hence, the LCS of -baar-adjectives can be defined as follows:

(12) The property of $y$ such that, for some $x_{\text {arb }}$, it is possible that $x$ PREDICATE $y$ (where $x$ PREDICATE $y$ is the LCS of the input verb)

Following Fagan (1988), we consider $x_{\text {arb }}$ as the expression of the generic interpretation of a variable, in this case of -baar-adjectives, and formally as an operator that binds the variable $x$. Hence, it will not project to the level of PAS. This accounts for the impossibility of the agentive door-phrase to cooccur with -baar-adjectives. The only remaining variable is the logical object variable, which projects as external argument on PAS. We assume that when LCS contains only one logical variable, this variable will in the unmarked case project as external argument (i.e. ergative verbs form an exceptional class in this respect).

If we wanted to describe deverbal -baar-suffixation as an operation on PAS instead of an operation on LCS, we would have to describe it as follows: delete the external argument, and make the internal argument external. However, this description does not express the fact that there is still an understood generic agentive subject for such adjectives. Moreover, this word formation rule has to apply to LCS anyway, because the 'potentiality' interpretation of such adjectives can only be expressed at that level. Therefore, the most straightforward and generalizing account of -baar-suffixation is the one in terms of an operation on the LCS of its base verbs, with predictable consequences for the level of PAS.

In the next section I will present another case of deverbal affixation which can only be stated insightfully and in a generalizing fashion in terms of an operation on LCS.

\section{VERBAL PREFIXATION AND LCS}

Dutch has a number of deverbal prefixes, among which be-. As shown in (13), the prefix be- attaches to verbs with different types of argument structure. Nevertheless, the output verbs always have the same PAS: $\underline{x}, \mathbf{y}$. That is, they are obligatorily transitive verbs. A uniform output makes it impossible to state the rule as an operation on PAS because we would then predict different output argument structures correlating with different input argument structures. Therefore, the rule must be stated as an operation on LCS. 

type of input verb:
a. external arg. only:
lopen
'to walk'
klimmen
'to climb'
b. with indirect int. arg.:
twijfelen aan iets
'doubt about something'
vechten met iemand
'fight with somebody'
slapen met iemand
'sleep with somebody'
c. with direct int. arg.:
schilderen
'to paint'
plakken
'to glue'
d. with dir. and indir. arg: iets roven van iemand 'rob something from somebody' iets planten in iets 'plant something in something'
output verb:
iets belopen
'walk on something'
iets beklimmen
'to climb on something'
iets betwijfelen
'doubt something'
iets bevechten
'fight something'
iemand beslapen
'lit. sleep on somebody'
iets beschilderen
'to put paint on something'
iets beplakken
'to put glue on something'
iemand beroven van iets
'to rob somebody by taking away something'
iets beplanten met iets
'plant something with something'

The same morphological process of be-prefixation occurs in the related Germanic languages German (cf. Günther 1986, Wunderlich 1987) and Frisian (Veenstra 1988). Both Günther and Wunderlich primarily deal with the subclass of be-prefixation exemplified in (13d). A similar alternation is found in English (cf. Rappaport et al. 1988), but without overt morphological marking:

a. to plant trees in the garden/to plant the garden with trees

b. to load hay onto the wagon/to load the wagon with hay

Günther's (1986) and Wunderlich's (1987) analyses of the German equivalents of the cases (13d) are essentially as follows: sentences with underived verbs and sentences with the derived be-counterparts are paraphrases of each other. Beprefixation only affects the syntactic realization of the different $\theta$-roles: with underived verbs, the Location is expressed as an indirect argument (i.e. as a PP with a specific preposition), whereas with the be-verbs the Location-role is the direct argument, and the original direct internal argument becomes the indirect one. This is illustrated in (15): 

a. Er giesst [Wasser $]_{\text {dir }}$ [auf die Blumen $]_{\text {ind }}$
'He pours water on the flowers'
b. Er begiesst [die Blumen] $]_{\text {dir }}$ [mit Wasser $]_{\text {ind }}$
'He covers the flowers with water'

In this view then, be-prefixation is not seen as a process that primarily affects LCS, but as an operation affecting PAS because it only affects the syntactic realization of what is assumed to be the common meaning of both the simplex verb and the derived $b e$-verb. ${ }^{3}$ Therefore, both Günther and Wunderlich consider this process as comparable to Passive formation.

Two objections must be raised to the kind of analysis proposed by Günther and Wunderlich. First, it is not expressed in this approach that the object of the derived verb is always an object that is completely affected by the action expressed by the verb (as a matter of fact, a very traditional observation concerning be-verbs). For instance, the expression de tuin met rozen beplanten 'to plant the garden with roses' implies that the garden is completely covered with roses, whereas this is not necessarily the case when the expression rozen in de tuin planten 'to plant roses in the garden' is used. In this connection the semantic opposition particularistic : holistic is also used. According to Wunderlich (1987: 303) it is not always the case that the object is completely affected. For instance, sentence (15b) does not necessarily mean that the flowers are completely covered with water. Although this may be correct, even in that case the phrasing with the be-verb suggests that somehow the flowers are completely affected, although the water may not completely cover the flowers.

The second point to be made is that by giving a special rule of be-prefixation for the verbs of type (13d), we do not express the generalization that, whatever the argument structure of the input verb may be, the argument structure of the output verb is always the same, as shown in (13).

Therefore, deverbal be-prefixation should be seen as a morphological process that creates verbs that express an action that completely affects the object of that action. Since affected objects always project as direct internal arguments on the level of PAS, the PAS, and hence the syntactic transitivity of all deverbal beverbs is completely predictable. The LCS of deverbal be-verbs is expressed in (16):

$x$ completely affects $y$ by executing the ACTION of P-ing, where $\mathrm{P}$ is the Predicate of the input verb.

This LCS generalizes across all kinds of input verbs, because the predicate itself is the only element taken over from the LCS of the input verb, not the arguments; the latter are created by (16).

This analysis implies that even in the case of transitive input verbs, the arguments of the output verb are created. This position is corroborated by the 
fact that transitive underived and derived verbs impose different selection restrictions on their arguments. For instance, the verb schilderen 'to paint' can cooccur with an effected object (as in een landschap schilderen 'to paint a landscape') whereas the object of beschilderen 'to cover with paint' is always an affected object. The same difference is found in the pair schrijven 'to write'/beschrijven 'to write on' (compare een brief schrijven 'to write a letter' to een vel papier beschrijven 'to cover a piece of paper with writing'. Consequently, in such cases the direct argument of the underived verb cannot be the same as that of the derived counterpart.

As shown in Booij and Van Haaften (1988) exactly the same holds for deverbal ver-prefixation in Dutch: the input verbs of ver-prefixation differ in argument structure, but the ver-verbs are always obligatorily transitive verbs. Therefore, ver-prefixation must also be described as a case of creation of argument structure. The common semantic aspect of ver-verbs is that the action referred to in the base word is directed toward the object in such a way that the object is really affected by the action. Similar word formation rules are those that prefix om-, door- or over- to a verb: they always create verbs with a direct internal argument, whatever the argument structure of the input verb:
type of input verb
a. ext. arg. only
schijnen 'shine'
output verb
woekeren 'grow rank' doorschijnen 'shine through' overwoekeren 'overgrow'
omschijnen 'shine around'
b. direct int. arg. zien 'see'
doorzien 'see through'
c. ind. int. argument denken aan iets
'think of something' overzien 'look over'
iets overdenken 'think about something' iets doordenken 'grasp something completely'
d. direct + ind. argument een gat in iets boren iets doorboren 'drill a hole in something' iets in iets wikkelen 'drill through something'
iets omwikkelen
'wrap something completely'

In (13d) we saw two pairs of verbs in which both the input verb and the output verb seem to have three arguments. Therefore, the question arises how we can deal with such cases, which suggest that the effect of be-prefixation has to do with PAS rather than with LCS. However, it should be observed that in expressions like de tuin met rozen beplanten 'to plant the garden with roses' it is 
always possible to omit the met-phrase, as is also observed for German by Günther (1986: 193). That is, we suggest that the met-phrase is an optional adjunct, rather than an argument. The adjunct status of such met-phrases is supported by the fact that they can be separated from the direct object by en wel:
a. *Hij beplant, en wel de tuin
'He plants, namely the garden'
b. Hij beplant de tuin, en wel met rozen
'He plants the garden, namely with roses'

The upshot of this analysis is that there is no formal similarity between beprefixation and the formation of passive verbs, as was suggested by Günther and Wunderlich: be-prefixation is an operation at the level of LCS, with concomitant changes at the level of PAS, whereas Verbal Passive formation is an example of a morphological operation that directly affects PAS in that it suppresses the syntactic realization of the external argument. As noted frequently in the literature, in passives the Agent argument has the status of an implicit argument, since it can function as a controller in passive sentences (Roeper 1987):

a. The boat was sunk to collect the insurance money

b. *The boat sank to collect the insurance money

In (19b), the to-infinitive construction cannot be used because for ergative verbs there is no implicit argument that can function as a controller.

We summarize our conclusions so far as follows: morphological rules can operate on two different levels of the lexical representation of verbs: LCS and PAS. When they apply at LCS, this may also affect PAS, because PAS is a projection of LCS. We have seen the following types of direct operation on PAS: (i) binding of one of the arguments (English -er binds the external argument of verbs, Dutch -sel binds the internal argument); (ii) suppression of an argument at PAS (in verbal passives, the external argument of the base verb is not realized syntactically, but can function as controller for the PRO-subject of $t o$-infinitives). Note also that we were able to account for the differences between English and Dutch deverbal -er-suffixation by assuming that the first process applies at PAS, and the second one at LCS. In the next section, we will see that the distinction between PAS and LCS is also crucial for a proper characterization of the differences between middle verbs and passive verbs.

\section{MIDDLE VERBS}

English has a productive rule of middle verb formation. As Fagan (1988) argues convincingly, middle verbs must be considered to be derived by a lexical rule, 
not by a syntactic movement rule. Fagan points out that the underlying subject of the middle verb is interpreted generically. For instance, according to her, sentence (20a) can be paraphrased as (20b):
a. This book reads easily
b. People, in general, can read this book easily

Fagan proposed to account for this observation on genericness by characterizing the rule of English middle formation as follows:
a. Assign $a r b$ to the external $\theta$-role
b. Externalize the direct $\theta$-role

Fagan assumes that by assigning the index $a r b$ to a role, it is "lexically saturated', and therefore it will not be realized syntactically. Clearly, then, middle formation is seen by Fagan as an operation that directly affects the level of PAS.

When we apply (21) to e.g. the verb to read, we get the following PAS for the middle verb to read:

$$
\text { read, } \underline{x}_{\text {arb }}, y(x=\text { Agent, } y=\text { Theme })
$$

As far as I can see, there is some unclarity here in having two external $\theta$-roles. Let us therefore assume that the saturation of the Agent role is expressed at the level of LCS, parallel to the representation of the implicit object of the intransitive to eat:

$$
\begin{aligned}
& \text { LCS: for some } x_{\text {arb }}, x \text { READ y } \\
& \text { PAS: } \mathrm{V}, \mathrm{y}
\end{aligned}
$$

Due to this operation on LCS, middle verbs are agentless and predictably intransitive, since there is only one free variable that can project to PAS. The fact that the original agent variable is bound, can also be observed in the ungrammaticality of sentences with middle verbs and agentive by-phrases:

*This book reads well by John

However, even then the semantic differences between middles and passives are not completely expressed. Fagan points out that "middles [...] are not used to report events, but to attribute a specific property to some object" (p. 200). The static nature of middle predicates excludes progressive forms as witnessed by the ill-formedness of *This book is reading easily. This static nature of middle predicates is not expressed by (23). It thus appears that a more adequate 
semantic characterization of middle formation is called for, in terms of an operation on LCS from which the proper PAS can be projected. I propose the following LCS for the middle verb read that also expresses the potentiality aspect of the semantic interpretation:

$$
\text { the property of } y \text { such that, for } x_{\text {arb }} \text {, it is possible that } x \text { READ } y
$$

In this LCS, the variable $x$ is bound by the operator $x_{\text {arb }}$ and hence only the variable $y$ can be projected on the level of PAS, as the external argument.

In Dutch, middle formation not only applies to transitive verbs, but also to verbs with an optional indirect internal argument (e.g. op een paard rijden 'to ride on a horse') and to intransitive verbs such as zingen 'to sing':

Dat paard rijdt lekker

That horse rides nicely

'On that horse, one can ride nicely'

(27) Het zingt hier gemakkelijk

It sings here easily

'One can sing here easily'

In (27) there is no external argument for the middle verb zingen, and the subject position is filled with the expletive pronoun het 'it'.

Thus, the following general semantic characterization of Dutch middle verbs can be given:

(28) the property (of $y$ ) such that for $x_{\text {arb }}$ it is possible that $[x \text { PREDICATE }(y)]_{\text {ACTION }}$

where $[x$ PREDICATE $(y)]$ stands for the LCS of the input verb. The optional $y$-variable corresponds to the direct or indirect internal argument of the input verb. Since LCS (28) contains at most one free variable, the PAS of middle verbs will either contain one, external, argument, as in (26), or no argument at all, as in (27).

It should be mentioned here that both passive formation and middle formation do not apply to ergative verbs, i.e. they only apply to verbs with an external argument. This is illustrated in (29) where passive formation and middle formation yield ungrammatical results:

\section{a. ${ }^{\star}$ Er wordt hier vaak gevallen} There is here frequently fallen

'One falls here frequently' 


\author{
b. *Het valt hier gauw \\ It falls here easily \\ 'One can easily fall here'
}

This may at first sight suggest that middle formation applies at the level of PAS, since it seems that the relevant class of input verbs is to be defined in terms of PAS-properties: verbs with an external argument. However, we also saw that middle formation not only affects the argument structure of the input verbs, but also implies other, semantic modifications. Hence, we have to assume that middle formation applies at the level of LCS. The class of verbs that undergo middle formation can also be defined at that level, namely as the class of ACTION verbs (this is already presupposed in (28)). Independent evidence for the correctness of this semantic definition of the class of input verbs is that psychological verbs such as ergeren 'to annoy', storen 'to disturb' and verbazen 'to amaze', which are non-ergative and have an external argument, cannot be subject to middle formation, whereas they do allow for passive formation, an operation on PAS:
a. Middle formation
*Jan ergert gemakkelijk
'John annoys easily'
b. Passive formation
Jan wordt gemakkelijk geërgerd
'John is easily annoyed'

This analysis of middle formation also accounts for the difference between middles and passives with respect to control phenomena. Unlike the implicit agent of passives, the lexically saturated agent variable of middles is not projected at PAS, and thus cannot function as controller:

a. The book was read to solve the problems

b. *This book reads easily to solve the problems

In sum, it seems to me that the differences between middle verbs and passives can receive an insightful description by making use of the difference between LCS and PAS: middle verbs are formed by an operation on LCS, with consequences for PAS, whereas passive verbs only differ from their active counterparts at the level of PAS: the external argument is present, but 'suppressed', i.e. it is not realized syntactically, although it can still function as a controller for PRO. This approach is in accordance with Williams' (1987) claim that control relations are to be stated at the level of argument structure, where 'implicit arguments' are available. The subjects of the verbal bases of 
-able-adjectives and middle verbs do not receive the status of implicit arguments, unlike the subjects of the bases of verbal passives.

\section{CONCLUSIONS}

Let me now briefly summarize the conclusions of this paper. The most important point was that morphological operations that affect syntactic valency should not always be characterized in terms of operations on argument structure, but often as operations at the level of Lexical Conceptual Structure. This situation is to be expected given the existence of two levels of lexical representation, LCS and PAS, which were also motivated for simplex verbs such as the two verbs to eat and the two verbs to break. Since PAS is a projection of LCS, morphology may also have effects on PAS due to changes at LCS.

Another conclusion is that the phenomena discussed above do not require that the arguments at the level of PAS are labeled for a specific $\theta$-role: generalizations that refer to PAS can be expressed in terms of the distinction between external and internal argument, and that between direct and indirect arguments.

At a more general level we saw the importance of semantics for a proper characterization of the distributional properties of derived words. In the words of Fagan (1988: 202):

This discussion [...] brings to light some of the problems encountered when one searches for syntactic explanations for linguistic phenomena without fully considering semantic alternatives. We cannot ignore the complex interaction of semantic and syntactic features that underly any given construction. If we give due consideration to all aspects of grammar (syntax, semantics, and so on) we will stand a better chance of more fully understanding the linguistic phenomena we set out to explore.

By showing that many morphological operations must be described in terms of operations at LCS, we established evidence for the crucial role of semantic generalizations and insights in morphology. What remains to be developed is a more fully articulated theory of the structure of representations at LCS, and of the linking or projection rules that relate LCS to PAS.

\section{NOTES}

* The research for this paper was carried out as part of research programme Lett $88 / 9$, Vrije Universiteit Amsterdam. I would like to thank the audiences at the University of Essex, the Vrije Universiteit Amsterdam, and the University of Lille for their reactions, and Ton van Haaften, Rochelle Lieber, the editor, and the anonymous referees for their comments on a previous version of this paper. 
1. Semantic notions like Activity (= Action) and Process are also indispensable for a correct characterization of the distribution of small clause complements of verbs (cf. Hoekstra 1988).

2. According to Randall (1982)-able-adjectives are similar to -baar-adjectives in that they do not allow for by-phrases.

3. As Wunderlich (1987: 300) observes, such an analysis conflicts with Williams' (1981) hypothesis that morphology cannot only affect internal arguments.

\section{REFERENCES}

Amritavalli, A. 1980. Expressing Cross-categorial Selectional Correspondences. An Alternative to the X-bar Syntax Approach. Linguistic Analysis 6. 305-343.

Anderson, S.R. 1977. Comments on the Paper by Wasow. In P.W. Culicover, T. Wasow, A. Akmajian (eds.) Formal Syntax. New York: Academic Press. 361-377.

Baker, M. 1988. Incorporation. Chicago: University of Chicago Press.

Booij, G.E. 1986. Form and Meaning in Morphology: the Case of Dutch 'Agent Nouns'. Linguistics 24. 503-517.

Booij, G.E. and T. van Haaften. 1988. The External Syntax of Derived Words, Evidence from Dutch. Yearbook of Morphology 1. 29-44.

Di Sciullo, A.-M. 1988. Formal Relations and Argument Structure. Paper given at the 3rd Int. Morphology Meeting, Krems, July 1988.

Fagan, S.M.B. 1988. The English Middle. Linguistic Inquiry 19. 181-204.

Günther, H. 1986. Wortbildung, Syntax, be-Verben und das Lexicon. Beiträge zur Geschichte der deutschen Sprache und Literatur 109. 179-201.

Hale, K. and S.J. Keyser. 1986. Some Transitivity Alternations in English. Lexicon Project Working Papers 7. Cambridge, Mass.: MIT.

Hoekstra, T. 1984. Transitivity. Dordrecht: Foris.

Hoekstra, T. 1988. Small Clause Results. Lingua 74. 101-139.

Jackendoff, R.S. 1983. Semantics and Cognition. Cambridge, Mass.: MIT Press.

Jackendoff, R.S. 1987. The Status of Thematic Relations in Linguistic Theory. Linguistic Inquiry 18. 369-412.

Knopper, R. 1984. On the Morphology of Ergative Verbs and the Polyfunctionality Principle. In H. Bennis and W.U.S. van Lessen Kloeke (eds.) Linguistics in the Netherlands 1984. Dordrecht: Foris. 119-128.

Levin, B. and M. Rappaport. 1986. The Formation of Adjectival Passives. Linguistic Inquiry 17. 623662.

Levin, B. and M. Rappaport. 1988. Non-event er-nominals: a Probe into Argument Structure. Linguistics 26. 1067-1084.

Marantz, A. 1984. On the Nature of Grammatical Relations. Cambridge, Mass.: MIT Press.

Randall, J. 1982. Morphology and Language Acquisition. Doctoral dissertation, University of Amherst.

Rappaport, M. 1983. On the Nature of Derived Nominals. In M. Levin, M. Rappaport and A. Zaenen (eds.) Papers in Lexical Functional Grammar. Bloomington, Ind.: IULC. 113-142.

Rappaport, M., B. Levin, and M. Laughren. 1988. Niveaux de représentation lexicale. Lexique 7. 13-32.

Roeper, Th. 1987. Implicit Arguments and the Head-Complement Relation. Linguistic Inquiry 18. 267-310,

Veenstra, D.H. 1988. Oer de Grammatika fan be-ferba. In S. Dyk and G. de Haan (eds.) Wurdfoarried en Wurdgrammatika. Ljouwert: Fryske Akademy. 137-174.

Williams, E. 1981. Argument Structure and Morphology. The Linguistic Review 1. 81-114. 
Williams, E. 1987. Implicit Arguments, the Binding Theory, and Control. Natural Language and Linguistic Theory 5. 151-180.

Wunderlich, D. 1987. An Investigation of Lexical Composition: the Case of German be-verbs. Linguistics 25. 283-331.

Zubizarreta, M-L. 1986. Levels of Representations in the Lexicon and in the Syntax. Dordrecht: Foris. 